Pesq. Vet. Bras. 36(2):77-82, fevereiro 2016 DOI: $10.1590 / \mathrm{S} 0100-736 \mathrm{X} 2016000200003$

\title{
Partial budget analysis of prepartum antimicrobial therapy and Escherichia coli J5 vaccination of dairy heifers and their effect on milk production and milk quality parameters ${ }^{1}$
}

INDEX TERMS: Mastitis, milk, antimicrobial treatment, vaccine, dairy cows.

RESUMO.- [Análise econômica da terapia antimicrobiana no pré-parto e da vacinação com Escherichia coli J5 em novilhas leiteiras e seu efeito sobre a produção e qualidade de leite.] 0 presente estudo objetivou realizar

\footnotetext{
${ }^{1}$ Received on June 10, 2015.

Accepted for publication on January 28, 2016.

Part of the MSc Dissertation of the first author presented at the PostGraduate Program in Animal Science of the Escola de Veterinária (EV), Universidade Federal de Minas Gerais (UFMG).

${ }^{2}$ Núcleo de Zootecnia, Instituto Federal de Minas Gerais (IFMG), Fazenda Varginha, Rodovia Bambuí-Medeiros Km 5, Cx. Postal 5, Bambuí, MG 38900-000, Brazil.

${ }^{3}$ Departamento de Tecnologia e Inspeção de Produtos de Origem Animal, EV-UFMG, Av. Presidente Antônio Carlos 6627, Pampulha, Belo Horizonte, MG 30123-970, Brazil. *Corresponding author: nogueirasouza@ yahoo.com.br

${ }^{4}$ Centro Nacional de Pesquisa de Gado de Leite, Empresa Brasileira de Pesquisa Agropecuária (Embrapa), Rua Eugênio do Nascimento 610, Dom Bosco, Juiz de Fora, MG 36038-330, Brazil.
}

uma análise econômica do tratamento antimicrobiano no pré-parto e/ou da vacinação com Escherihia coli J5 em novilhas leiteiras, e seu efeito sobre a produção e qualidade de leite. Portanto, utilizou-se o delineamento split-splot em esquema fatorial, no qual 33 novilhas da raça Holandesa foram divididas aleatoriamente em quatro grupos: (G1) antimicroianoterapia no pré-parto e vacinação com E. coli J5, (G2) antimicrobianoterapia no pré-parto, (G3) vacinação com E. coli J5 e (G4) controle. Amostras compostas de leite foram coletadas para contagem de células somáticas, contagem bacteriana total e composição do leite 15 dias após o parto, e a cada 15 dias até o término do experimento. A análise bacteriológica do leite foi realizada ao término do experimento. A produção de leite e a incidência dos casos clínicos de mastite, assim como, os custos associados à antimicrobianoterapia no pré-parto e/ou vacinação com E. coli J5 foram registrados. Os resultados demonstraram redução 
dos casos clínicos de mastite com a implementação das medidas preventivas resultando no menor volume de leite descartado $(0,99,1,01,1,04$ e $3,98 \%$ para os animais dos grupos G1, G2, G3 e G4, respectivemente) e maior benefício econômico. Desta forma, em rebanhos bem manejados, a implementação da antimicrobianoterapia no pré-parto e vacinação com E. coli 55 e novilhas pode reduzir a quantidade de antimicrobianos necessário para o tratamento de casos de mastite clínica durante a lactação, resultando em menor número de dias em que o leite é descartado.

TERMOS DE INDEXAÇÃO: Mastite, leite, tratamento antimicrobiano, vacina, vaca leiteira.

\section{INTRODUCTION}

Mastitis is the most costly disease for dairy farmers and the dairy industry, and although losses have been well characterized in mature cows, intramammary infections (IMIs) in primigravid heifers have been a more recent focus of study (Borm et al. 2006, Fox et al. 2009). Historically, control of mastitis has been driven primarily by economic considerations and public health (Heikkilä et al. 2012, Langoni 2013).

Notably, the greatest development of milk-producing tissue in the udder occurs during the first pregnancy. Therefore, it is important to protect the mammary gland from pathogenic microorganisms to ensure maximum milk production during the first lactation (Nickerson et al. 2009, Piepers et al. 2009). Unfortunately, most dairy farmers assume pre-calving heifers as uninfected. However, IMIs in heifers is not uncommon, although it does tend to be less prevalent than in older cows (Costa et al. 1996, Fox et al. 2009, Nickerson et al. 2009, Sampimon et al. 2009). IMIs in heifers have been detected as early as at the age of puberty, but the rate of new infections is higher in the last few days of pregnancy (Compton et al. 2007, Compton et al. 2009, De Vliegher et al. 2012).

First-calving heifers have a higher incidence rate of clinical mastitis than older cows, with the highest rate of disease occurring in the first few days after calving (Parker et al. 2007, Compton et al. 2009, Piepers et al. 2009). In the last few decades with the improvement of subclinical mastitis control programs, which has led to herds with a lower somatic cell count (SCC), clinical mastitis has become a major problem in many well-managed dairy herds that have successfully controlled contagious pathogens (Green et al. 2004).

The average cost of subclinical heifer mastitis has only been calculated once (Hujips et al. 2009), however the economic cost of clinical mastitis in heifers around calving has never been reported in the literature (De Vliegher et al. 2012). With this in mind, the average costs per case of clinical mastitis, clinical mastitis by Gram-negative bacteria generated the highest cost per case when compared with Gram-positive bacteria and other pathogens that caused clinical mastitis (Cha et al. 2011). Here, the partial budgeting was used to develop a deterministic simulation model to estimate the net cost or benefit of dry antimicrobials and/or Escherichia coli J5 vaccination. Partial budgeting is a relative simple method to calculate economic effects. It is useful in studies that compare relatively small changes in a system such as implementation of a control program vs. no implementation of a control program (Swinkels et al. 2005).

Clinical mastitis have been associated with increased use of drug therapy, increase in discarded milk, and increased risk of residues appearing in the milk supply. For these reasons, reductions in heifer mastitis by prevention strategies such as antimicrobial therapy and vaccination can lead to increased profitability to the dairy operator and a more wholesome milk supply. Coliform mastitis continues to increases in importance as a disease complex of dairy cattle, which leads to death of cattle, milk production loss, veterinary and treatment costs, excess labor demand, premature culling, decrease quality of milk, and discarded milk (Wilson et al. 2008, Heikkilä et al 2012). Most of commercially vaccines against coliforms mastitis are E. coli J5 vaccines. The J5 strain has a relatively exposed core antigen, sometimes, called the J5 core antigen that is present in many kinds of gram-negative bacteria (Wilson \& González 2003). Thus, to the best of our knowledge, this is the first report that has investigated the effects of antimicrobial therapy and E. coli J5 vaccination alone or in association, on milk quality, and milk production, along with their economic implication, in dairy heifers.

Thus, present study sought to explore whether prepartum antimicrobial therapy and/or $E$. coli $J 5$ vaccination in dairy heifers influenced the milk production, somatic cell count, milk composition, and total bacteria counts in milk. In addition, the economic effects of the implementation of these control programs were also estimated on the first 190 days in milk.

\section{MATERIALS AND METHODS}

The present study was conducted in a well-managed commercial dairy herd with low bulk tank somatic cell counts $(\leq 250,000$ cells $\mathrm{mL}^{-1}$ ) and a history of clinical mastitis by Gram-negative bacteria located in Minas Gerais State, Brazil. Out of this herd, 33 Holstein heifers were randomly selected and enrolled in four groups using a full factorial split-plot design. Cows were milked three times/ day, housed in free stalls, and all animals received the same basal diet, which had been formulated to meet their requirements (NRC 2001).

The treatment groups were as follows: $\mathrm{G} 1, \mathrm{n}=8$, intramammary infusion of all quarters with a antimicrobial dry cow preparation containing $400 \mathrm{mg}$ of novobiocin sodium plus 200,000 IU of penicillin G procaine (Albadry Plus ${ }^{\circledR}$, Pfizer Animal Health) 60 days before the expected parturition, as proposed by Trinidad et al. (1990) and vaccination with an Escherichia coli J5 bacterin (Enviracor J5 ${ }^{\circledR}$, Pfizer Animal Health) at 60 and 30 days before the expected parturition and 15 after calving; G2, $n=9$, intramammary infusion of all quarters with an antimicrobial dry cow preparation containing $400 \mathrm{mg}$ of novobiocin sodium plus 200,000 IU of penicillin G procaine (Albadry Plus ${ }^{\circledR}$, Pfizer Animal Health) 60 days before the expected parturition; $\mathrm{G} 3, \mathrm{n}=8$, vaccination with an $E$. coli J5 bacterin (Enviracor J $5^{\circledR}$; Pfizer Animal Health) at 60 and 30 days before the expected parturition and 15 days after calving and $\mathrm{G} 4, \mathrm{n}=8$, no intramammary infusion and no vaccination.

Clinical mastitis was assessed by udder examination and a strip cup test for the presence of clots, flakes or otherwise obviously abnormal secretion at every milking. When a clinical 
case of mastitis was detected, the animals were treated with an intramammary infusion of lactation cow antimicrobial preparation once a day for three days or until clinical cure occurred. Any episode occurring more than 14 days after the previous episode was considered a new clinical mastitis case (Barkema et al. 1998). When a recurrent case of clinical mastitis appeared, the animal was treated with an infusion of antimicrobial preparation at all milking times for three days or until clinical cure was observed.

Composite milk samples for SCC and milk composition (fat, lactose, protein and total solid contents) were collected 15 days after calving and every 15 days until the end of the experiment (190 days of lactation) in a 40-mL vial containing microtablets of bronopol (2-bromo-2-nitropane-1,3-diol) and analyzed using a calibrated Bentley CombSystem $2300{ }^{\circledR}$ unit (Chaska, USA). Composite milk samples for total bacteria count (TBC) were also collected in a vial containing azidiol at the same time points described above. The TBC was determined using a Bactocount ICB $150^{\circledR}$ unit (Bentley Instruments, Chaska, USA). Milk production measurement was assessed every milking for each cow using a milking meter system (DeLaval ALPRO ${ }^{\mathrm{TM}}$, DeLaval ${ }^{\circledR}$, Sweden).

Composite milk samples from each cow were collected aseptically for bacteriological analysis at the end of the experiment (190 days of lactation). The milk samples were kept frozen until cultured. Bacterial analysis was conducted by culturing $0.01 \mathrm{~mL}$ of each sample on $5 \%$ ovine blood agar plates and MacConkey agar. The plates were incubated for 48 hours at $35^{\circ} \mathrm{C}$, which was followed by Gram staining, observation of colony morphology and biochemical testing (Oliver et al. 2004). For Gram-positive cocci, catalase tests was used to differentiate between the catalase-positive staphylococci and catalase-negative streptococci. Morphology, hemolysis patterns, coagulase, DNAse testing and pigment production were used to distinguish Staphylococcus aureus from CNS. The streptococci were subdivided into esculin-positive streptococci (Streptococcus uberis) and esculin-negative streptococci (S. agalactiae and S. dysgalactiae). Coliforms, including Escherichia coli, Klebsiella spp. and Enterobacter spp., were differentiated from each other and from other Gram-negative bacteria based on appearance on MacConkey agar, $\mathrm{KOH}$ testing, triple sugar iron reactions, indole production and motility. A milk sample was considered culture-positive when the growth of $\geq 10$ similar colonies was detected, except for those infected with $S$. aureus or $S$. agalactiae, which were considered as culture-positive when the growth of $\geq 1$ colony was detected. Samples yielding colonies of $\geq$ 3 different bacterial species were considered to be contaminated.

Economic effects are calculated as total revenues weighed against total costs. The partial budget analysis per cow during the present trial were estimated by the cost of the mastitis prevention strategy, the cost of the clinical cases of mastitis, and the difference in milk yield. The costs of the mastitis prevention strategy were the dry antimicrobials and/or E. coli J5 vaccination, the labor time and support material required to implement the vaccination and antimicrobials (teat disinfectant, paper towels, needle and alcohol 70\%). The costs of a clinical case of mastitis include milk withdrawal, costs of treatment, labor time and the materials necessary to implement mastitis treatment. The difference in mean milk production of all treatments groups (G1, G2 and G3) during the trial period compared with the control group (G4) was multiplied by the milk price paid by the dairy industry to dairy producers (USD/liter of milk) to estimate the economic benefits. The bacterial culture and the culling costs were not evaluated here.

First, for statistical analysis, the distribution of all variables was examined through the use of normal probability plots using the Anderson-Darling test. All SCCs and TBCs were log 10 transformed, as their distribution was not normal. Student's t test was applied to evaluate differences in SCC, TBC, milk composition and milk production. The percentage of days that milk was discarded was compared using the chi-square test. The statistical analyses were performed using SAS statistical software (Statistical Analysis System, Release 9.1, 2002; SAS Institute Inc., Cary, NC). The results are reported as the mean \pm standard deviation. The significance was set at $P \leq 0.05$, unless otherwise indicated.

\section{RESULTS}

In the present study, the control untreated and unvaccinated heifers (G4) displayed a higher incidence of clinical mastitis (10 cases) compared with heifers that received prepartum antimicrobial infusion (G2; 3 cases), heifers that received prepartum antimicrobial infusion and was vaccinated with an $E$. coli J5 bacterin (G1; 2 cases) and heifers that was vaccinated with an E. coli J5 bacterin (G3; 2 cases). This fact led to a higher number of days that milk was discarded due to the treatment of clinical cases of mastitis and the withdrawal periods of antimicrobials (Table 1). Most of the clinical cases of mastitis in our study occurred in the first weeks of lactation or after a period of heavy rains.

\section{Table 1. Number of days that milk was discarded due to the treatment of clinical mastitis}

\begin{tabular}{cccc}
\hline Groups & $\begin{array}{c}\text { Days that milk } \\
\text { was discarded }\end{array}$ & Days without discarded & $\begin{array}{c}\text { \% of days that milk } \\
\text { was discarded }\end{array}$ \\
\hline G1 & $15^{\mathrm{b}}$ & $1,512^{\mathrm{a}}$ & 0.99 \\
$\mathrm{G} 2$ & $18^{\mathrm{b}}$ & $1,791^{\mathrm{a}}$ & 1.01 \\
$\mathrm{G} 3$ & $16^{\mathrm{b}}$ & $1,528^{\mathrm{a}}$ & 1.04 \\
G4 & $59^{\mathrm{a}}$ & $1,480^{\mathrm{b}}$ & 3.98 \\
Total & 108 & 6,311 & \\
\hline
\end{tabular}

ab Values within lines with different superscript letters differ significantly $(\mathrm{P}<0.001)$ according to $\chi 2$ test. $\mathrm{G} 1=$ heifers that received prepartum antimicrobial infusion and was vaccinated with an Escherichia coli J5 bacterin, G2 = heifers that received prepartum antimicrobial infusion, G3 = heifers that was vaccinated with an E. coli J5 bacterin, G4 = heifers that received no intramammary infusion and no vaccination.

The percentage of bacteriologically positive milk samples at the end of trial was higher in heifers that received antimicrobial treatment (G2, $44.0 \%$ ) followed by the control untreated and unvaccinated heifers (G4, $25.0 \%)$. The lowest percentage of infected animals was observed in vaccinated and treated animals (G1) and vaccinated heifers (G3, 12.5\%; Table 2).

The percentages of lactose, protein and total solid content in composite milk samples and the total bacteria count (TBC) were not significantly different among groups (data not shown). Otherwise, the fat content values throughout the study were lower for G2 $(3.30 \pm 0.70 \%)$ compared with G1 (3.54 $\pm 0.62 \% ; P=0.011)$ and G3 (3.51 $\pm 0.66 \% ; P=0.019)$. However, no significant difference was found for the control group (G4; $3.46 \pm 0.67 \%$ ) compared to the other groups.

No significant difference in logarithmic SCC $\mathrm{mL}^{-1}$ was observed in the first samples (15 days after parturition) (G1 $=5.21 \pm 0.54 ; \mathrm{G} 2=5.23 \pm 0.65 ; \mathrm{G} 3=5.00 \pm 0.56 ; \mathrm{G} 4=4.91 \pm 0.43$; $P=0.61)$. The logarithmic SCC $\mathrm{mL}^{-1}$ throughout the entire study was higher in G2 (4.88 \pm 0.62$)$ than G4 (4.66 \pm 0.49 ; $P=0.03)$. No significant difference was found between G2 and G1 (4.84 $\pm 0.60 ; P=0.77)$ or G3 (4.68 $\pm 0.40 ; P=0.11)$.

The mean milk production was $30.75( \pm 2.90) \mathrm{kg} /$ day, $29.61( \pm 4.01) \mathrm{kg} /$ day, $27.66( \pm 6.24) \mathrm{kg} /$ day and 26.57 
Table 2. Bacteriological results for composite milk samples at the end of present study

\begin{tabular}{|c|c|c|c|}
\hline Group & $\begin{array}{l}\text { Number of } \\
\text { animals }\end{array}$ & Isolated bacteria & $\begin{array}{c}\text { Infected quarters } \\
(\%)\end{array}$ \\
\hline G1 & $\begin{array}{l}1 \\
1 \\
6\end{array}$ & $\begin{array}{c}\text { Streptococcus esculin positive } \\
\text { Contaminated } \\
\text { Negative }\end{array}$ & 12.5 \\
\hline G2 & $\begin{array}{l}2 \\
1 \\
1 \\
2 \\
3\end{array}$ & $\begin{array}{c}\text { CNS } \\
\text { CNS / Streptococcus esculin negative } \\
\text { Staphylococcus aureus } \\
\text { Contaminated } \\
\text { Negative }\end{array}$ & 44.0 \\
\hline G3 & $\begin{array}{l}1 \\
7\end{array}$ & $\begin{array}{l}\text { Pseudomonas sp. } \\
\text { Negative }\end{array}$ & 12.5 \\
\hline G4 & $\begin{array}{l}1 \\
1 \\
2 \\
4\end{array}$ & $\begin{array}{c}\text { CNS } \\
\text { CNS/Klebsiella sp. } \\
\text { Contaminated } \\
\text { Negative }\end{array}$ & 25.0 \\
\hline
\end{tabular}

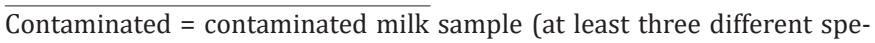
cies were isolated). CNS = Coagulase-negative staphylococci. G1 = heifers that received prepartum antimicrobial infusion and was vaccinated with an Escherichia coli J5 bacterin, G2 = heifers that received prepartum antimicrobial infusion, G3 = heifers that was vaccinated with an E. coli J5 bacterin, G4 = heifers that received no intramammary infusion and no vaccination.

$( \pm 5.03) \mathrm{kg} /$ day for G1, G2, G3 and G4, respectively, and was not significantly different among groups. However, a tendency toward a higher milk production in G1 compared with G4 was observed $(P=0.06)$.

The partial budget analysis of the antimicrobial treatment and/or E. coli J5 vaccination are shown in Table 3.

Table 3. Partial budget analysis per heifer due to prepartum antimicrobial treatment and/or Escherichia coli J5 vaccination

\begin{tabular}{ccccc}
\hline Group & G1 & G2 & G3 & G4 \\
\hline $\begin{array}{c}\text { Costs of antimicrobial and/ } \\
\text { or vaccine (USD) }\end{array}$ & 143.36 & 80.80 & 62.56 & 00.0 \\
$\begin{array}{c}\text { Milk discarded (USD) } \\
\text { Labor cost to apply the }\end{array}$ & 96.26 & 110.38 & 68.46 & 328.62 \\
$\begin{array}{c}\text { antimicrobial and/or vaccine (USD) } \\
\quad \text { Material used to apply }\end{array}$ & 1.52 & 1.35 & 0.54 & 0.00 \\
$\begin{array}{c}\text { antimicrobial and/or vaccine } \\
\text { Antimicrobials used to treat } \\
\text { clinical mastitis case (USD) }\end{array}$ & 14.13 & 18.09 & 21.37 & 111.21 \\
$\begin{array}{c}\text { Labor and material used to } \\
\text { apply antimicrobial (USD) }\end{array}$ & 0.53 & 0.80 & 0.53 & 2.65 \\
$\begin{array}{c}\text { Costs } \\
\text { Increased milk production } \\
\quad \text { (USD) }\end{array}$ & $\mathbf{2 5 6 . 1}$ & $\mathbf{2 1 1 . 6 6}$ & $\mathbf{1 5 3 . 5 9}$ & $\mathbf{4 4 2 . 0 6}$ \\
$\begin{array}{c}\text { Benefit } \\
\text { Net profit (USD) }\end{array}$ & $\mathbf{1 6 1 . 1 6}$ & 119.96 & 42.28 & 0.00 \\
& $\mathbf{- 8 9 . 9 4}$ & $\mathbf{- 9 1 . 7 0}$ & $\mathbf{- 1 1 1 . 3 1}$ & $\mathbf{- 4 4 2 . 0 6}$
\end{tabular}

G1 = heifers that received prepartum antimicrobial infusion and was vaccinated with an Escherichia coli J5 bacterin, G2 = heifers that received prepartum antimicrobial infusion, G3 = heifers that was vaccinated with an $E$. coli J5 bacterin, G4 = heifers that received no intramammary infusion and no vaccination.

\section{DISCUSSION}

Our results demonstrate a positive effect of prepartum vaccination and/or treatment of dairy heifers on the rate of clinical mastitis. Consequently, less milk was discarded due to antimicrobial treatment. This finding explains the higher economic benefit of antimicrobial treatment and/or E. coli $\mathrm{J} 5$ vaccination in heifers compared with untreated and unvaccinated control heifers, under the conditions of our experiment.

Borm et al. (2006) observed that prepartum intramammary therapy did not significantly affect milk production or linear SCC in the first 200 days of lactation, although it had a significant effect on the cure rate of infected mammary glands. Conversely, Sampimon et al. (2009) reported lower SCC and higher milk yield over the first lactation in antimicrobial-treated dairy heifers. This indicates that potential herd-specific factors not yet fully understood may play a role in heifer mastitis (De Vliegher et al. 2012).

In regards to antimicrobial treatment, Sampimon et al. (2009) reported that the cumulative risk of clinical mastitis throughout lactation was much lower in dairy heifers that received prepartum antimicrobial therapy compared with untreated ones. It is known that E. coli J5 bacterin treatment does not prevent IMIs, although the treatment reduces the severity of clinical signs of mastitis (Hogan et al. 1992). Indeed, dairy cows that contracted Escherichia coli mastitis and had been vaccinated with E. coli J5 bacterin presented $75 \%$ lower milk loss than unvaccinated cows, and the hazard of being culled for all reasons and mastitis were significantly lower for J5 vaccinates (Wilson et al. 2009). Altogether, these data can explain, at least in part, the lower amount of milk discarded due to treatment of clinical cases of mastitis and a reduced lactating antimicrobial withdrawal period in animals that received antimicrobial treated and/or E. coli J5-vaccinated dairy heifers found here.

We did not observe any benefits of antimicrobial and/ or E. coli J5 vaccination on milk composition and TBCs throughout the experiment period or any benefits for the bacteriological status of the udders at the end of the experiment. In contrast, Oliver et al. (2003) and Sampimon et al. (2009) demonstrated that prepartum antimicrobial-treated heifers had a lower prevalence of culture-positive milk samples at calving, which, in turn, could lead to higher milk production. Although in our study, we did not perform any bacteriological analysis at calving, it should be kept in mind that coagulase-negative staphylococci (CNS) is the most prevalent cause of subclinical mastitis in heifers (Oliver et al. 2007, Fox et al. 2009, Piepers et al 2009, Tenhagen et al. 2009, De Vliegher et al. 2012), as described in Brazilian dairy herds (Costa et al. 1996) and observed here in the middle of first lactation. The non-significant difference in composite milk SCC in the first milk sampled here (15 days post-partum) pointed out to no significant difference in prevalence of mastitis pathogens among groups. Therefore, it should kept in mind that the composite SCC cannot allow us to discriminate infected and uninfected animals using SCC as an indicator of inflammation (mastitis), as CNS microorganisms often lead to a low quarter milk SCC (Schukken et al. 2009, Schwarz et al. 2010), and most of their IMIs are cured in early lactation (Oliver et al. 2007, Nickerson et al. 2009, Piepers et al. 2009, Piepers et al. 2010, De Vliegher et al. 2012).

In addition, some studies have demonstrated that subclinical mastitis from CNS does not have a large impact on future milk production and udder health (Nickerson et al. 
2009, Piepers et al. 2009, Schukken et al. 2009, Piepers et al. 2010, De Vliegher et al. 2012). Though prepartum antimicrobial therapy has been proposed as a single and effective way of controlling heifer mastitis, the positive long-lasting effects on SCC and milk yield do not always occur, ruling out the universal recommendation of this practice. When CNS are the major cause of IMIs in heifers, productivity is not affected, making prepartum treatment redundant and even unwanted (De Vliegher et al. 2012). Furthermore, prepartum treatment has been successful in reducing the prevalence of infection but had no effect on SCC or milk yield during the subsequent lactation (Nickerson 2009). Thus, if most of the pre-existing CNS IMIs were cured using antimicrobials, it did not necessarily lead to higher milk production. This finding may explain, at least in part, the non-significant difference in milk production observed in the present study for all groups.

Therefore, though a tendency toward a higher milk production in both antimicrobial treatment and E. coli J5 vaccination was observed in the present study, it may not be linked to the effect of contagious pathogens on milk production (no significant difference on milk SCC at 15 days after calving). These findings may be related to the lower clinical mastitis rates observed in this study, and the reduction of the severity of the clinical cases of mastitis and the lower milk losses reported in clinical cases of mastitis in J5-vaccinated cows (Wilson et al. 2009). Indeed, Gentilini et al. (2012) and Molina et al. (2013) also found higher milk production, a reduction in the occurrence of clinical mastitis cases by E. coli in the first 100 days of lactation in J5-vaccinated dairy cows, although no significant difference was found in SCC. Similarly, Maia et al. (2013) observed a lower persistence of clinical mastitis cases in J5-vaccinated cows.

The higher percentage of infected quarters in heifers that received antimicrobial drugs compared with control heifers is most likely related to new infections acquired during lactation and the higher SCC and lower fat content observed for this group. The degradation of fat by milk SCC (Le Roux et al. 2003), together with the upregulation of genes related to immune response functions and the downregulation of genes involved in fat metabolism (Buitenhuis et al. 2011), can explain, at least in part, the higher SCC and lower fat content in these animals. In contrast, the percentage of infected animals was lower in heifers that received antimicrobial and $E$. coli $\mathrm{J} 5$ vaccination or $E$. coli $\mathrm{J} 5$ vaccination compared with control animals.

In regard to the higher incidence rate of clinical mastitis in first-calving compared with multiparous cows (Parker et al. 2007, Compton et al. 2009, Piepers et al. 2009, De Vliegher et al. 2012) and the results of the present study, the use of antimicrobial therapy and/or E. coli J5 vaccination can be justified by the lower incidence of clinical mastitis and consequently the lower volume of discarded milk and the related economic benefits, especially in well-managed dairy herds (Green et al. 2004).

Thus, our results indicated that in well-managed dairy herds, the prevention of heifer mastitis by vaccination with an E. coli J5 bacterin and antimicrobial therapy can reduce the amount of antimicrobials needed to treat clinical mastitis cases and the days of discarded milk leading to economical benefits.

Acknowledgements.- The authors are grateful for financial support from the Pró-Reitoria de Pesquisa of the Universidade Federal de Minas Gerais and Laboratório de Análise da Qualidade do Leite (LabUFMG) of the Escola de Veterinária from the Universidade Federal de Minas Gerais.

\section{REFERENCES}

Barkema H.W., Schukken Y.H., Lam T.J., Beiboer M.L., Wilmink H., Benedictus G. \& Brand A. 1998. Incidence of clinical mastitis in dairy herds grouped in three categories of bulk milk somatic cell counts. J. Dairy Sci. 81:411-419.

Borm A.A., Fox L.K., Leslie K.E., Hogan J.S., Andrew S.M., Moyes K.M., Oliver S.P., Schukken Y.H., Hancock D.D., Gaskins C.T., Owens W.E. \& Norman C. 2006. Effects of prepartum antibiotic therapy on udder health, milk production, and reproductive performance in dairy heifers. J. Dairy Sci. 89:2090-2098.

Buitenhuis B., Rontved C.M., Edwards S.M., Ingvarstsen K.L. \& Sorensen P. 2011. In depth analysis of genes and pathways of the mammary gland involved in the pathogenesis of bovine Escherichia coli-mastitis. BMC Genomics 12:130.

Cha E., Bar D., Hertl J.A., Tauer L.W., Nennett G., González R.N., Schukken Y.H., Welcome F.L. \& Gröhn Y.T. 2011. The cost and management of different types of clinical mastitis in dairy cows estimated by dynamic programming. J. Dairy Sci. 94:4476-4487.

Compton C.W.R., Heuer C., Parker K.I. \& McDougall S. 2007. Epidemiology of mastitis in pasture-grazed peripartum dairy heifers and its effects on productivity. J. Dairy Sci. 90:4157-4170.

Compton C.W.R., Cursons R.T.M., Barnett C.M.E. \& McDougall S. 2009. Expression of innate resistance factors in mammary secretion from periparturient dairy heifers and their association with subsequent infection status. Vet. Immunol. Immunopathol. 127:357-364.

Costa E.O., Melville P.A., Ribeiro A.R., Watanabe E., Viani F.C. \& White C.R. 1996. Prevalence of intramammary infections in primigravid Brazilian dairy heifers. Prev. Vet. Med. 29:151-155.

De Vliegher S., Fox L.K., Piepers S., McDougall S. \& Barkema H.W. 2012. Mastitis in dairy heifers: nature of disease, potential impact, prevention and control. J. Dairy Sci. 95:1025-1040.

Gentilini M.B., Molina L.R. \& Carvalho A.U. 2012. Utilização da vacina Escherichia coli na imunização de novilhas leiteiras contra mastites causadas por E. coli. Arq. Bras. Med. Vet. Zootec. 64:67-74.

Green M.J., Green L.E., Shukken Y.H., Bradley A.J., Peeler E.J., Barkema H.W., De Hass Y., Collis V.J. \& Medley G.F. 2004. Somatic cell count distributions during lactation predict clinical mastitis. J. Dairy Sci. 87:1256-1264.

Hujips K., De Vliegher S., Lam T. \& Hogeveen H. 2009. Cost estimation of heifer mastitis in early lactation by stochastic modeling. Vet. Microbiol. 134:121:127.

Fox L.K. 2009. Prevalence, incidence and risk factors of heifer mastitis. Vet. Microbiol. 134:82-88.

Heikkilä A.-M., Nousiainen J.I. \& Pyörälä S. 2012. Costs of clinical mastitis with special reference to premature culling. J. Dairy Sci. 95:139-150.

Hogan J.S., Smith K.L., Todhunter D.A. \& Schenberger P.S. 1992. Field trial to determine effcicacy of an Escherichia coli J5 mastitis vaccine. J. Dairy Sci. 75:78-84.

Langoni H. 2013. Qualidade do leite: utopia sem um programa sério de monitoramento da ocorrência da mastite bovina. Pesq. Vet. Bras. 33: 620-626.

Le Roux Y., Laurent F. \& Moussaoui F. 2003. Polymorphonuclear proteolytic activity and milk composition change. Vet. Res. 34:629-645.

Maia P.V., Molina L.R., Facury Filho E.J., Gonçalves R.L., Moreira L.P.V. \& Carvalho A.U. 2013. Vacinação com Escherichia coli J5 no pré-parto e ocorrência de mastite e produção de leite de vacas mestiças leiteiras. Arq. Bras. Med. Vet. Zoot. 65:1367-1375.

Molina L.R., Gentilini M.B., Carvalho A.U., Facury Filho E.J., Moreira G.H.F.A., 
Moreira L.P.V. \& Gonçalves R.L. 2013. Utilização da vacina Escherichia coli J5 na imunização de vacas leiteiras contra mastites causadas por $E$. coli. Pesq. Vet. Bras. 33:291-298.

National Research Council 2001. Nutrient Requirements of Dairy Cattle. National Academies Press, Washington, DC.

Nickerson S.C. 2009. Control of heifer mastitis: antimicrobial treatment an overview. Vet. Microbiol. 134:128-135.

Oliver S.P., Lewis M.J., Gillespie B.E., Dowlen H.H., Jaenicke E.C. \& Roberts R.K. 2003. Prepartum antibiotic treatment of heifers: milk production, milk quality and economic benefit. J. Dairy Sci. 86:1187-1193.

Oliver S.P., Lewis M.J., Gillespie B.E., Dowlen H.H., Jaenicke E.C. \& Roberts R.K. 2004. Microbiological Procedures for the Diagnosis of Bovine Udder Infection and Determination of Milk Quality. 4th ed. National Mastitis Council, Verona. 47p.

Oliver S.P., Headrick S.I., Gillespie B.E., Lewis M.J., Johnson D.L., Lamar K.C., Moorehead H., Dowlen H.H. \& Hallberg J.W. 2007. Intramammary infections in heifers during early lactation following intramammary infusion of pirlimycin hydrochloride or penicillin-novobiocin at the first milking after parturition. J. Dairy Res. 74:211-271.

Parker K.I., Compton C.W.R., Anniss F.M., Weir A.M. \& McDougall S. 2007. Management of dairy heifers and its relationships with the incidence of clinical mastitis. N. Z. Vet. J. 55:208-216.

Piepers S., De Vliegher S., De Kruif A., Opsomer G. \& Barkema H.W. 2009. Impact of intramammary infections in dairy heifers on future udder health, milk production, and culling. Vet. Microbiol. 134:113-120.

Piepers S., Opsomer G., Barkema H.W., de Kruif A. \& De Vliegher S. 2010. Heifers infected with coagulase-negative staphylococci in early lactation have fewer cases of clinical mastitis and higher milk production in the first lactation than noninfected heifers. J. Dairy Sci. 93:2014-2024.
Sampimon O.C., De Vliegher S., Barkema H.W., Sol J. \& Lam T.J.G.M. 2009. Effect of prepartum dry cow antibiotic treatment in dairy heifers on udder health and milk production. J. Dairy Sci 92:4395-4403.

Schukken Y.H., González R.N., Tikofsky L.J., Schulte H.F., Santisteban C.G., Welcome F.L., Bennett G.J., Zurakowski M.J. \& Zadoks R.N. 2009. CNS mastitis: nothing to worry about? Vet. Microbiol. 134:9-14.

Schwarz D., Diesterbeck U.S., Failing K., König S., Brügemann K., Zschöck M., Wolter W. \& Czerny C.P. 2010. Somatic cell counts and bacteriological status in quarter foremilk samples of cows in Hesse, Germany - a longitudinal study. J. Dairy Sci. 93:5716-5728.

Swinkels J.M., Hogeveen H. \& Zadoks R.N. 2005. A partial budget model to estimate economic benefits of lactational treatment of subclinical Staphylococcus aureus mastitis. J. Dairy Sci. 88:4273-4287.

Tenhagen B.-A., Hansen I., Reinecke A. \& Heuwieser W. 2009. Prevalence of pathogens in milk samples of dairy cows with clinical mastitis and in heifers at first parturition. J. Dairy Res. 76:179-187.

Trinidad P., Nickerson S.C., Alley T.K. \& Adkinson R.W. 1990. Efficacy of intramammary treatment in unbred and primigravid dairy heifers. J. Am. Vet. Med. Assoc. 197:465-470.

Wilson D.J. \& González R.N. 2003. Vaccination strategies for reducing clinical severity of coliform mastitis. Vet. Clin. Food Anim. 19:187-197.

Wilson D.J., Grohn Y.T., Bennett G.J., González R.N., Schukken Y.H. \& Spatz J. 2008. Milk production change following clinical mastitis and reproductive performance compared among J5 vaccinated and control dairy cattle. J. Dairy Sci. 91:3869-3879.

Wilson D.J., Mallard B.A., Burton J.L., Schukken Y.H. \& Grohn Y.T. 2009. Association of Escherichia coli J5-specific serum antibody responses with clinical mastitis outcome for J5 vaccinate and control dairy cattle. Clin. Vaccine Immunol. 16:209-217. 